\title{
CORE COMPETENCES FOR ITEM
}

\section{A Model}

Ian Selwood and Christopher O'Mahony

with Rakesh Bhatt, Bill Davy, Margaret Haughey, Hatano Kazuhiko, Javier Osorio, and Tuulikki Paturi.

Key words: Competences, training, management, decision-making

\section{INTRODUCTION}

As part of the 2002 ITEM Conference, a Discussion Group was formed with the mandate to explore the core competences required for ITEM. It was recognised by the group that, whereas IT for Educational Management has existed in educational institutions for almost 20 years, the history of its introduction was characterised by a generally ad-hoc approach to implementation. In particular, it was perceived that attempts to introduce new technologies into educational institutions often lacked coherent and effective training programmes, to the extent that the literature reports unsatisfactory use of ICT in teaching, learning and administration (Lambert \& Nolan 2002, Ofsted 2002, Newton 2002).

The discussion group sought to develop a model or framework, which would enable educational institutions to plan their ITEM training and achieve an ITEM-competent staff.

\section{BACKGROUND}

In discussing the issue of how to train school managers to use managerial school information systems Visscher and Branderhost (2001) point out that there is strong empirical evidence that user training strongly influences the

The original version of this chapter was revised: The copyright line was incorrect. This has been corrected. The Erratum to this chapter is available at DOI: 10.1007/978-0-387-35689-1_19 
degree of information system usage. Selwood (1995) highlighted the problems concerning the lack of differentiation of training for different levels of school personnel in the England and Wales - Headteachers, trained alongside school secretaries. More recently, Selwood and Drenoyianni (1997) discussed the problems of training senior managers in the use of their school's Management Information System (MIS) to support their decisionmaking. Donnelly (2000) claimed that there were three levels of training appropriate to both the leadership team and administrative staff - training in generic software, training in the use of school-specific MIS software, and training in the use of the Internet. Additionally he stressed the need for the leadership team to be trained in how to use data to improve educational standards. Visscher and Branderhost (2001) specified five skill areas that they felt were needed by school staff:

1. Recognition of the value of information systems, and development of a school policy;

2. Determination of the type of information they need for their work, or for a specific problem;

3. Discovering how they can get information from their school MIS;

4. Interpreting information from their school MIS;

5. Using information from their school MIS for decision-making and policy-evaluation.

In the USA the Collaborative for Technology Standards for School Administrators have produced a set of "Technology Standards for School Administrators" (TSSA Collaborative 2001). However, whilst these are comprehensive they cover all aspects of technology including its use to support teaching and learning. These standards and are aimed at not only school based education managers, but also those at a district level. Thus, they need deconstructing in order to extract standards for ITEM.

In England and Wales, currently the government is in the process of promoting its Information Management Strategy (IMS 2000). As part of this, two documents concerned with competences have been produced: one is a self-evaluation form for Information Management and ICT Competences (DfES, 2002a); the other is aimed at identifying who does what in terms of administration activities (DfES 2002b).

The group felt that whilst many of the documents referred to above were useful, in highlighting the problems and some of the competences that were needed for the effective use of ITEM, none of them really described the core competences for ITEM. Furthermore, those that did detail competences tended to concentrate on operational competences at the expense of tactical and strategic competences. 
3. THE MODEL

\subsection{The X Axis: ITEM Dimensions}

We believe that the best way to open the lid on the ITEM black-box is to deconstruct our basic terms. Thus, four core dimensions present themselves - Information, Technology, Education and Management. ITEM links these four dimensions inextricably. It is in the interactions of these four dimensions that ITEM has its uniqueness.

\subsection{The Y Axis: Organisational Levels - Operational, Tactical, and Strategic}

The management process is primarily concerned with decision-making. Drawn from the management literature decision making can occur at three different levels operational, tactical, and strategic. Whenever for example, headteachers and governing bodies in a school form a vision of where the school is going establish aims and objectives prioritise them and develop a plan for the accomplishment of these objectives, they are involved in strategic decision-making. Whenever they are making decisions concerned with the implementation of the school's development plan (e.g. appoint or dismiss teaching or other staff), their decisions may be considered as tactical. Finally, whenever they have to carry out clear and specific tasks (e.g. ordering supplies) they are making operational decisions. An alternative approach in considering these organisational levels is to do so in terms of the degree of structured thinking, whereby operational decisions are highly structured, tactical decisions are semi-structured, and strategic decisions tend to be highly unstructured.

\subsection{The Z Axis - Stages of Growth}

The members of the discussion group felt that it was important to reflect the degree of sophistication of the organisation's IT effort. To this end, the group looked to well-exercised 'stages of growth' theories, the most popular in this arena being Nolan (1979), Visscher (1991) and Galliers \& Sutherland (1991).

Each of these theorists offered a model with certain relevance to the ITEM competence debate. Both the Nolan and Galliers \& Sutherland models were perceived as too generic for the ITEM domain. At the same time, although the Visscher model was perceived as being the most relevant, 
we wanted to modify the stage labels to more closely reflect stages of sophistication. After some debate, the stage labels chosen were therefore Initiation, Expansion, and Embedded.

Table 17-1. Stages of growth compared [Please provide a caption for this table]

\begin{tabular}{clcl}
\hline Stage & \multicolumn{1}{c}{ Nolan } & Visscher & \multicolumn{1}{c}{ Galliers \& Sutherland } \\
\hline I & Initiation & Initiation & Ad Hocracy \\
II & Contagion & & Starting the Foundations \\
III & Control & Expansion & Centralised Dictatorship \\
IV & Integration & Integration & Democratic Dialectic and Cooperation \\
V & Data Administration & & Entrepreneurial Opportunity \\
VI & Maturity & & The Age of Aquarius \\
\hline
\end{tabular}

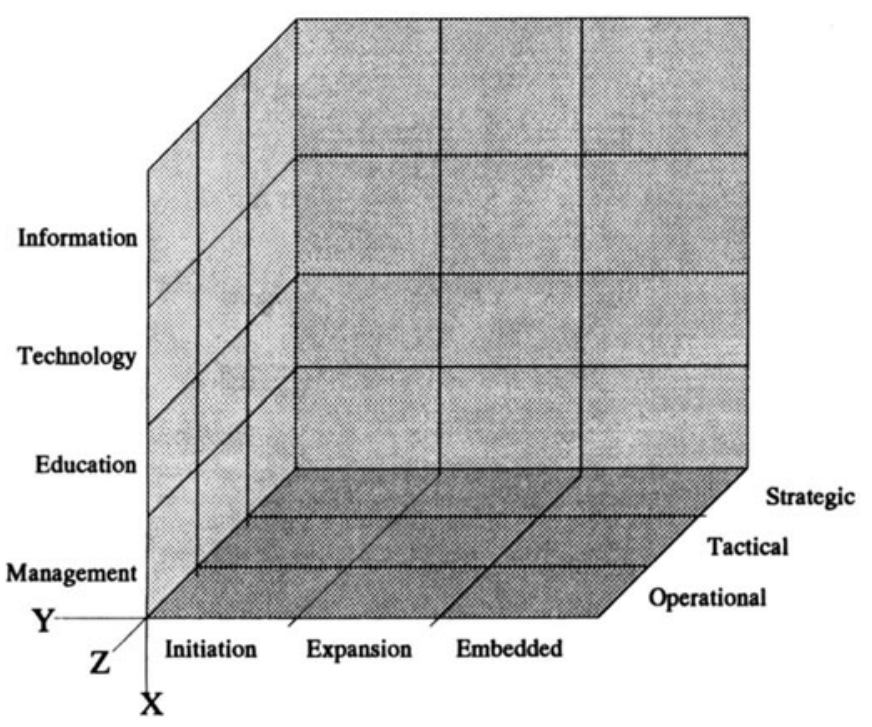

Figure 17-1. The proposed three dimensional model of ITEM Competences

\subsection{Advantages of the ITEM Competence Model}

The proposed model offered certain advantages, as follows:

- It enables us to map existing policies and programmes, and to investigate goodness of fit of those policies and programmes;

- It enables us to map ITEM competences to existing job descriptions within educational institutions;

- It is platform-independent;

- It is descriptive;

- It is prescriptive; 
- It helps us in the development of more appropriate policies and programmes for ITEM competences.

- It assists in the development of an appropriate post-graduate ITEM curriculum;

- It enables the certification of other courses against the criteria noted in these competences.

\subsection{The Dimension Space}

\begin{tabular}{llll}
\hline & \multicolumn{1}{c}{ Operational } & \multicolumn{1}{c}{ Tactical } & \multicolumn{1}{c}{ Strategic } \\
\hline Information & Data & Information & Knowledge \\
Technology & Transaction & Management & Knowledge Management / \\
& Processing & Information Systems & EIS / Expert Systems \\
Education & Routine & Projects & Visioning \\
Management & Individual & Team / Department & Whole-School \\
\hline
\end{tabular}

\subsection{Operational Competences}

\begin{tabular}{llll}
\hline & \multicolumn{1}{c}{ Initiation } & \multicolumn{1}{c}{ Expansion } & \multicolumn{1}{c}{ Embedded } \\
\hline Information & Recognise \& edit data & Link \& Interpret data & $\begin{array}{l}\text { Leverage \& Exploit } \\
\text { data }\end{array}$ \\
Technology & $\begin{array}{l}\text { Initiate \& Manipulate } \\
\text { transactions }\end{array}$ & $\begin{array}{l}\text { Link \& Interpret } \\
\text { transactions }\end{array}$ & $\begin{array}{l}\text { Leverage \& Exploit } \\
\text { transactions }\end{array}$ \\
$\begin{array}{l}\text { Education } \\
\text { Management }\end{array}$ & $\begin{array}{l}\text { Routine Recording } \\
\text { Organise my tasks }\end{array}$ & $\begin{array}{l}\text { Routine Reporting } \\
\text { Prioritise my tasks }\end{array}$ & $\begin{array}{l}\text { Exception Reporting } \\
\text { Control \& Transform } \\
\text { my tasks }\end{array}$ \\
\hline
\end{tabular}

\subsection{Tactical Competences}

\begin{tabular}{|c|c|c|c|}
\hline & Initiation & Expansion & Embedded \\
\hline Information & $\begin{array}{l}\text { Recognise \& edit } \\
\text { information }\end{array}$ & $\begin{array}{l}\text { Link \& Interpret } \\
\text { Information }\end{array}$ & $\begin{array}{l}\text { Leverage \& Exploit } \\
\text { Information }\end{array}$ \\
\hline Technology & $\begin{array}{l}\text { Initiate \& Manipulate } \\
\text { MIS }\end{array}$ & Link \& analyse MIS & Leverage \& Exploit MIS \\
\hline Education & Recognise projects & $\begin{array}{l}\text { Link \& interpret } \\
\text { Projects }\end{array}$ & $\begin{array}{l}\text { Leverage \& Exploit } \\
\text { projects }\end{array}$ \\
\hline Management & Organise my team & $\begin{array}{l}\text { Control \& Prioritise } \\
\text { my team }\end{array}$ & $\begin{array}{l}\text { Leverage \& Transform } \\
\text { my team. }\end{array}$ \\
\hline
\end{tabular}




\subsection{Strategic Competences}

\begin{tabular}{llll}
\hline & \multicolumn{1}{c}{ Initiation } & \multicolumn{1}{c}{ Expansion } & \multicolumn{1}{c}{ Embedded } \\
\hline Information & $\begin{array}{l}\text { Recognise \& } \\
\text { manipulate knowledge } \\
\text { Technology }\end{array}$ & $\begin{array}{l}\text { Link \& interpret } \\
\text { knowledge } \\
\text { Initiate \& Manipulate }\end{array}$ & $\begin{array}{l}\text { Leverage \& exploit } \\
\text { knowledge }\end{array}$ \\
EIS & $\begin{array}{l}\text { Leverage \& Exploit } \\
\text { Eecognise Vision }\end{array}$ & Communicate Vision & $\begin{array}{l}\text { Leverage \& Exploit } \\
\text { (share) Vision }\end{array}$ \\
Management & $\begin{array}{l}\text { Organise my } \\
\text { institution }\end{array}$ & $\begin{array}{l}\text { Control \& Prioritise my } \\
\text { institution }\end{array}$ & $\begin{array}{l}\text { Leverage \& Transform } \\
\text { my institution }\end{array}$ \\
\hline
\end{tabular}

\section{CONCLUSIONS AND RECOMMENDATIONS}

The Discussion Group had thus identified 36 core ITEM competences four dimensions (Information, Technology, Education, Management) at three levels (Operational, Tactical, Strategic) for three degrees of sophistication (Initiation, Expansion, Embedded). It is apparent that as one gains competence at one level and moves to the next, the cognitive processes and decision-making involved move from Structured (Level 1) to Semistructured (Level 2) to Unstructured (Level 3). As a corollary to this, it will be expected that Level 1 competence is a pre-requisite for transition to Level 2, and Level 2 competence is a pre-requisite for transition to Level 3.

The Group recommended that subsequent work should be devoted to two key activities:

a) To populate each of the 36 core ITEM competences with practical, reallife examples; and

b) To use this ITEM Competence Grid to benchmark existing ITEM curricula;

As time passes, the technology landscape will inevitably change, with different competences emerging. It will be important to review the framework after two years.

\section{REFERENCES}

DfEE (2000). Information Management Strategy for Schools and LEAS.

http://www.dfee.gov.uk/ims/summary.brief.shtm. DfEE. London

DfES (2002a). Staff ICT competences framework 21 Aug.

http://www.teachernet.gov.uk/docbank/index.cfm?id=2820. DfES. London

DfES (2002b). Who does what Aug 21.

http://www.teachernet.gov.uk/docbank/index.cfm?id=2821. DfES. London 
Donnelly, J. (2000). Information Management Strategy for Schools and Local Education Authorities - Report on Training Needs. http://dfes.gov.uk/ims/JDReportfinal.rtf . DfES, London

Galliers, R.G. \& Sutherland A.R., (1991), Information systems management and strategy formulation: the 'stages of growth' model revisited, Journal of Information Systems, 1, 1991.

Lambert, M.J., \& Nolan, C.J.P., (2003). Managing learning environments in schools: developing ICT capable teachers. In Management of Education in The Information Age The Role of ICT. Edited by Selwood I, Fung A, O'Mahony C. Kluwer for IFIP. London

Newton, L., (2003). Management and the use of ICT in subject teaching - integration for learning. In Management of Education in The Information Age - The Role of ICT. Edited by Selwood I, Fung A, O'Mahony C. Kluwer for IFIP. London

Nolan, R.L., (1979), Managing the Crises in Data Processing, Harvard Business Review, 57, 2, March 1979, pp 115-126.

Ofsted (2002). ICT in Schools, Effect of Government Initiatives. http://www.ofsted.gov.uk/public/docs01/ictreport.pdf . DfES , London.

Selwood, I. (1995). The Development of ITEM in England and Wales in Information Technology in Educational Management. Edited by Ben Zion Barta, Moshe Telem and Yaffa Gev. Chapman Hall for IFIP, London, UK.

Selwood, I.D. \& Drenoyianni, H. (1997). Administration, Management and IT in Education in Information Technology in Educational Management for the Schools of the Future. Edited by Fung A, Visscher A, Barta B and Teather D. Chapman \& Hall for IFIP. London, UK.

TSSA (2001). Technology Standards for Scool Administrators. http://cnets.iste.org/tssa/docs/tssa.pdf . TSSA Collaborative/ISTE, Eugene.

Visscher, A.J. \& Brandhorst, E.M. (2001). How should School Managers be Trained for Managerial School Information System Usage? In Pathways to Institutional Improvement with Information Technology in Educational Management. Edited by Nolan, C.J.P., Fung, A.C.W., \& Brown, M.A. Kluwer for IFIP. London

Visscher, A.J., (1991), School administrative computing: a framework for analysis, Journal of Research on Computing in Education, 24, 1, Fall 1991, pp 1-19. 